\title{
CONTEMPORARY TENDENCIES IN THE ORGANIZATION OF ALL- EUROPEAN DEFENSE RESEARCH
}

\author{
Zhivo Petrov \\ Assoc. Prof. Ph.D., Faculty of Aviation, Vasil Levski National Military University, Dolna Mitropoliya, \\ District Pleven, Bulgaria, zhpetrov@gmail.com
}

\begin{abstract}
The main task of providing military and economic protection is the creation of conditions for sustainable development while also maintaining the capabilities of the state's military-economic and military-technical potential. Maintaining these capabilities at a level necessary for the implementation of the defense policy and ensuring the reliable fulfillment of military needs during peacetime, in the immediate threat of aggression or in case of armed hostilities.
\end{abstract}

Keywords: modern trends, defense scientific research, armed forces defense, economic security.

\section{INTRODUCTION}

The main task of providing military and economic protection is the creation of conditions for sustainable development while also maintaining the capabilities of the state's military-economic and military-technical potential. Maintaining these capabilities at a level necessary for the implementation of the defense policy and ensuring the reliable fulfillment of military needs during peacetime, in the immediate threat of aggression or in case of armed hostilities.

Although a number of initiatives have been undertaken in recent years the European defense industry is characterized by insufficient scale, level and quality of investments. The Member States of the European Union note the lack of cooperation among themselves. Over $80 \%$ of purchases and over $90 \%$ of the (R\&T) Research and Technology is carried out on a domestic level. The current state of the industry is too fragmented - for example the availability of 178 different weapons systems (only 30 are present in the USA). The low level of coordination in the defense planning leads to inefficiency in the use of the allocated funds, excessive duplication and inadequate deployment of the armed forces. The attraction of funds from the EU is desirable for the production of single armament. In order to be more effective future defense research development programs need to be included into an integrated approach that covers all aspects of the problem and combines elements of different strategies (the domestic market, the global European policy for defense and security, research etc.).

\section{ANALYSIS OF THE TRENDS IN THE ORGANIZATION OF THE EUROPEAN DEFENSE RESEARCH}

Following the 1998 Saint-Malo Summit, European countries have taken a number of steps to "formulate a general defense policy under a general foreign security policy". Its mission is to enable the EU to "have the 
capacity for autonomous action, backed by credible armed forces, decision-making mechanisms for their use and preparedness to respond to international crises".

Among these measures, special attention is paid to defense research. With all the participating organizations being: The European Space Agency (ESA), Organisation for Joint Armament Cooperation (OCCAR), Western European Arms Group (WEAG) and the European intergovernmental project promoting the restructuring of the European defense industry (Lol-FA) with all the listed organizations being intergovernmental. The most successful was the creation of the European Defense Agency (EDA) in 2004, which was initiated on the basis of a joint statement formally approved by the European Council. Such transformations give mixed results. The Western European Arms Group (WEAG), despite its positive contribution, it was disbanded in 2005 as its tasks became duplicative with the advent of the European Defense Agency. The European Space Agency (ESA) and the Organisation for Joint Armament Cooperation (OCCAR) can both be considered being more successful. However while the number of the major joint military programs being assigned to the Organisation for Joint Armament Cooperation (OCCAR) from EU Member States is increasing the European Space Agency (ESA) is fundamentally and perhaps already completely reorienting to work on civilian programs. With the advent of EAO and the collaboration of the Organisation for Joint Armament Cooperation (OCCAR), the European intergovernmental project to promote the restructuring of the European defense industry (Lol-FA) takes the role of a "brain thrust" and lobbying power to support or counteract the activities of the European Commission. With regards to the defense research, following the signing of the Implementing Arrangement/IA in 2003 the fourth subcommittee responsible for planning joint research activities has been dissolved and a Group of Research Directors/GRD has been set up. The GRD has been set up for "Encouraging the coordination of joint research activities, increasing the knowledge on modern technologies and promoting technological development and innovation"." In addition the national representatives of Member States initiate the Memorandum of Understanding" (EUROPA MoU), in which the principles of information exchange for the needs of both the scientific and technical cooperation. The Scientific Leadership Group (GRD) is still an important body for improving European cooperation within the framework of the Memorandum of Understanding, although Member States cannot agree on a pandect for handling transnational defense companies and closer cooperation in R\&T (Antonov, Hristozov, 2018).

The Scientific Leadership Team (GRD) is also working closely with EOA and R\&T experts. It sponsors subgroups on advanced technologies and R\&T environmental cooperation.

As far as the European Defense Agency (EDA) is concerned, its activities have so far been recognized as ineffective.The EDA has not become an agency responsible for the development of European military capabilities, research and development of weapons.In essence, the EDA is outside the major armaments programs of the Member States such as MALE-UAV or FCAS. This is the responsibility of the Member States that have not yet implemented a defense cooperation mechanism called "Long-Term Organized Military-Technical Cooperation" (PESCO) which aims to give real signification to the EOA, making it a natural instrument for the implementation of joint European military programs in the field of research and procurement, funded by financial contributions from participating Member States. In principle, there is already a well-developed mechanism in the form of the Organization for the Development and Production of Arms Cooperation (OCCAR) and thus it is more convenient for countries to operate under this mechanism than within the EOA framework. The EOA may not be in the administrative position to absorb OCCAR. However, even with budgetary constraints, the EOA can be of a great benefit to national agencies in supplying weapons when solving problems that are related both to armament requirements and to technological problems.Despite the wide variety of mechanisms and organizations, the number of European defense programs and projects has been decreasing overall since 2006. Defense spending on R\&T has been reduced twice compared to a reduction in defense spending (down $14.7 \%$ ) and thus suffered the most from the cuts in EU Member States' budgets. This trend is also fueled by the global financial and economic crisis (2008-2009), which further drives EU countries to return to national forms of investment. In 2014, the European Joint Defense R\&T amounted to 172 million EUR - 8.6\% of the cost of all national and joint European R\&T.

Later, some EU supranational bodies responded to a sharp drop in the cost of military (defense) research. The first EU advisory document highlighting the importance of defense research is the European Commission's Official Communication of 5 December 2007 entitled "Strategy for strengthening and enhancing the competitiveness of the European defense industry". A call for concrete action to counteract the negative effects of the reduction in military spending is also stated in the Official Report of the European Commission on 24th of July 2013. It is also proposed that CSDP research be supported, including within the framework of the program "Preparatory plan for defense research development activities" and also recommends "Focusing on those areas of research that most clearly define the needs of the EU for 
weaponry while also seeking interaction with national research programs. " The idea was immediately endorsed by the European Parliament in a resolution adopted on 21 November 2013, which supports the European Commission's intention to launch a preparatory program for EU research funding in support of CSDP activities and invites the European Commission to take concrete action suggestions for this program.

The European Commission has also prepared a number of proposals for the Horizon 2020 scientific program. This program is focused not only on military research. At the stage of basic research, it is very difficult for them to classify technology for civilian or military purposes. Thus, it is proposed to pay particular attention to organizations dealing with the basic sciences (TRL levels 1 to 3 ) that can be used for both defense and civilian purposes. For example, basic research relies on test centers and industrial facilities (wind tunnels, shipyards, military academies, advanced computer networks, microelectronics, etc.) that are heavily loaded to keep them in good condition. The European Commission provides a significant portion of Horizon 2020 funding for the creation or upgrade of research centers and for the development of lowmaturity technologies, taking into account the specificities of military constraints. Horizon 2020 program provides the opportunity for the exploration of dual-use technologies but the amount of funds allocated for the development of such technologies in 2016 is only 164 million EUR (against an average volume of 7 billion EUR annually) (Antonov, 2017).

In the fall of 2014, the European Parliament voted on a "Pilot Project for the Development of Defense Research", developing the mechanism and thus paving the way for the subsequent "Preparatory Action Plan for the Development of Defense Research".

From 2013 to 2015, EU activities to further develop programs in this field have been delayed due to debate and negotiations on the legality of the EU's participation in it. European defense research is concentrated almost exclusively in three countries: France, the United Kingdom and Germany who have invested the most in research and development. For example the joint investments of the three states in 2013 accounts for $92 \%$ and $86 \%$, respectively in the field of European defense research and development. In addition in France and the UK a significant portion of the defense research investments are spent on nuclear defense. After two decades of insufficient funding the European defense industry enterprises lack the technological skills to create next-generation equipment due to a lack of technology such as robotics, artificial intelligence, separate tactical weapons systems, lasers, infrared networks, radar stations for detection and monitoring of both areal and space threats not to mention missile defense and extremely sophisticated command and control systems. The above listed has a significant negative impact on the European defense technology and industrial capabilities which risks losing export markets, high-skilled employees, industrial capacity and its overall global competitiveness.

Thanks to the "Strategy in the field of defense innovations" better known as the "Third Counterbalance development Strategy" investment in military R\&T will increase even more. China's defense research budget is estimated to be more than twice than the US's defense budget (approximately 20 billion euro). No European country can afford such an increase in investment for military R\&T. Only a single principle of attitude can create the necessary thrust although the intergovernmental approach has failed to initiate this process in the last 15 years.

The European Commission is considering changes to the management system of the European Defense Agency. With the changes being a significant increase in its budget and the possibility that the European defense agency may absorb the Organization for cooperation in the development and production of weaponry. On the other hand a special structure can be created - similar to OCCAR - in the form of a joint enterprise. It is proposed that EU defense planning processes be harmonized. In 2018 the development of the missing elements for the defense planning is initiated. These elements include: a new "Weaponry Development Plan", "Joint Weaponry Acquisition Plan", including the "Defense Research Strategy" and the "Purchasing Policy".

On November $30^{\text {th }} 2016$ a European Defense Action Plan was launched suggesting:

1. The creation of a European Defense fund;

2. Promoting investments in small and medium sized enterprises (MSE); starting enterprises or other suppliers through the European structural and investment funds and the European Investment bank.

3. Increasing efficiency during the implementation of the two EU directives in relation to military procurement and the movement of weaponry within the borders of the EU (the main goal being the creation of a European weaponry market).

In June 2017 the European Commission issued a formal statement on the creation of a European Defense Fund. The fund includes work in two directions. 
The first direction is the so-called research development window. From 2017 the EU intends to offer unrecompensed research funds for joint research in innovative defense products and technologies that are fully and directly funded by the EU budget. Funding is planned not only through grants - the possibility of using a mechanism for purchasing defense research in advance is also considered.Such projects will require the involvement of research institutes and companies from several Member States and small and medium sized enterprises including those engaged in dual-use innovations. Specific rules on intellectual property rights are foreseen to be developed taking into account the experience from the Preparatory Action on Defense Research / PADR.

Projects that qualify and have the necessary requirements for funding from the EU budget are concentrated in the priority fields previously approved by the Member States. Fields such as electronics, metamaterials, encryption applications, robotics. Funding is planned through sub-programs that include:

- Preparation plan for the execution of an event for research in the field of defense with a budget of 90 million euro till the end of 2019;

- European program for scientific research in the field of defense (European Defense Research Program) carried in 2018. The European commission has promised to propose a special EU defense program with an annual budget of 500 million euro after 2020 which can make the EU one of the largest defense research investor in Europe.

The second direction is related to the manufacture and purchase of weaponry. In this area the EU offers a mechanism for co-financing and practical support from the European Commission. 500 million-euro is upfront for 2019 and 2020 of which $€ 245$ million are already approved for 2019. The European Defense Industrial Development Program (EDIDP) is expected to give 1 billion-euro annually. The program will include state funding with an expected multiplier effect of five.

Therefore, the program can generate a total investment of 5 billion-euro yearly increasing the defense potential after the year 2020. The EDIDP Regulation was approved by the European Parliament and the European Council and the European Defense Industry Development Program has been operating since early 2019.

The initiative „window for weaponry creation“ is established on two levels:

- The first level is open to all member states and must consist of a "main structure“. The level should define the general framework for support of member states and provide operational instruments for the development of specific projects on the basis of common rules and the use of appropriate legal and financial instruments. Furthermore it could also help to resolve discrepancies in the budgetary needs of member states;

- The second level should consist of specific projects for the creation of joint models for equipment based on voluntary participation by Member States. The approval of financial and operational decisions for each project will have to be made with accordance with the rules established at the level of the main structure.

The creation of joint models for equipment will have to be funded by the united installments of MemberStates which have decided to participate. This will ensure stable co-financing for such projects. Each instalment should be limited to individual projects which must be determined in advance. Therefore, projects must be financially independent and limited in terms of time and scale with the exception of all forms of interfinancial obligations between projects.

In cases where approval is also required the main structure and / or separate projects can be used to issue debt instruments related to the projects. Such instruments can be reinforced either through special payment lines transferring payment to Member States for each project or through additional guarantees made either by the share capital on a separate project level or on a main structure level. In the latter case the main structure may start on its own capital basis.

National capital' contribution to "The weapon creation window" will be considered as "one-off" in accordance with the "Stability and Growth Pact", which means that they will be discussed of structures "Budgetary efforts", expected to be undertaken by member-states. The same regime will apply to guarantees to the extent, insofar as they affect the deficit or the debts.

The contribution from the national capital towards the „window for weaponry creation"will be considered as "One-off" in accordance with the pact for stability and growth which means that the contributions will be discussed (taken into account) by the structural 'budgetary efforts' that Member States are expected to undertake. The same approach will also be applied in accordance with guarantees to the extent that they affect the deficit and / or debt obligations. 
The European Commission has demonstrated its readiness to consider all options for financing the 'Window for weaponry creation' from the EU budget in line with European treaties. For example the European Commission does not exclude the possibility of involvement first and foremost in the development of technology and the demonstration of research projects including prototyping. The European Commission is also considering supporting and developing feasibility studies and the preparation of test centers.

It is expected that EU budget will also help products and technologies in particular dual-use ones by covering administrative costs. The European commission also declared its readiness to support the initiative 'Window for weaponry creation' with its financial and technological experience. This should take into account Member States' experience and ongoing work within the EOA on the creation of a Cooperative Facility Mechanism (this amount is $2.5 \%$ of total national defense spending within the EU and $14 \%$ of national defense spending).

The European Commission has set an amount of 5 billion-euro annually as an investment in the development of the defense potential after the year 2020 as a target goal (this amount is $2.5 \%$ of the total national defense spending within the EU and $14 \%$ of national weaponry spending and intelligence). It can also fill the gap in achieving the goal agreed by the EOA Member States which represents $35 \%$ of the cost of purchasing military equipment in joint projects.

Qualification of the priorities and responsibility (the right to own equipment models) for the creation of weaponry remains for the Member states consideration.

Only joint projects involving at least three participants from several Member States will be eligible as well as a share of the total budget allocated to projects involving cross-border participation of small and mediumsized enterprises. The EU will co-finance the development of prototypes but only when Member States commit to buying the final product. Projects designed by the Member States under the „Long-term Organized Military-Technical Cooperation mechanism"will benefit from a higher percentage of EU co-financing (10\% bonus).

As a result after the year 2020 the EU promises to initiate an ambitious European Defense Research Program (EDRP) for the development of scientific research in the field of defense. Particular attention should be paid to the research of organizations involved in the development of scientific and technical basis and working on fundamental research (levels from 1 to 3 on the TRL scale) that can be used for defense purposes. In the next Multiannual Financial Development Program for the period 2021-2027 the European Union proposes to launch a special European defense research development scheme including "mid-level" mature technologies.

In order to create public procurements for defense until 2023-2025 it is proposed for an agreement to be reached about the second stage of the European program for the development of scientific research in the field of defense including co-financing from the EU and its Member States. For example according to Art. 185 of the Treaty on the Functioning of the European Union (TFEU) and for the purpose of establishing effective demonstration models (levels 7 and 8 from the TRL scale).

Specialized structures for the implementation of military programs in accordance with Art. 185 of the Treaty on the Functioning of the European Union may be organized by EOA or OCCAR.

The European Defense Fund will prove to be successful only if it can meet Europe's basic weaponry needs. In order to identify these needs it is essential that a sustainable defense planning process is made at EU level.

The development of scientific research in the field of defense with the participation of all European countries at EU level is an integral part in the process for the creation of the European Armed Forces in the future.

Separate appropriation for scientific research this time will be available for all EU states. The purchase of developed models of equipment will also be carried out jointly (part of the armament and military equipment will be partially joint).

Pan-European defense planning processes are also being developed. Since 2004 the European Defense Agency has done a great deal of work. The EOA in accordance with its level of administrative resources draws up military development plans and entices countries that have expressed willingness to participate in their implementation.

The level of administrative resources avaliable to the European Commission is much higher. After the program is adopted by EU countries in 2018 there will be a real opportunity for the acceleration of the integration processes of the European defense component. 
This can be seen as a test of the political will of the Member States to enhance cooperation in the field of defense. Although there is still uncertainty progress has been made in this area in recent years. The European Commission has clearly identified overall defense as a priority for the EU and is leading this process which is supported by the European Council.

It can be assumed that the existing cooperation system in the field of defense will help at least in the initial stages that the guaranteed guidelines in this regard are met. In the future interstate cooperation will be strengthened. It is possible that European allies may prefer to follow the example of the United States in building various forms of production associations. Such forms will become more widespread in connection with scientific and technical research for civilian use (Terziev, Petkov, Krastev, 2018d-m).

\section{SCIENTIFIC AND TECHNICAL RESERVE, TECHNOLOGY BROKER AND CONVERSION POTENTIAL IN THE DEFENSE ECONOMY}

Scientists from developed countries have long thought about the need for special protection for scientific discoveries.

There should also be an opportunity for information exchange, technology transfer and avaliablity to the best constructor solutions. Today we all have to work on the task of creating a unified information base for research and development in the defense industry. Diffrent develppments for the creation of new products, not only within the framework of the state defense procurement. Conducting various new developments and new products which are implemented under other programs not only within the framework of the state's defense order.

We are faced with the task that all developers have to be able to connect to this closed database and the fact that it must be unconditionally closed because not all technologies are subject to disclosure. For various reasons this may just be a 'know-how' that we in no way want to share. Furthermore we don't want to disclose the capabilities that we truly employ today. The professionals, the people working in the defense industry need to have access to that knowledge and information. The concept of a technology broker has been emerging relatively recently. However an important process preceding the emergence of this concept and phenomenon is the creation of a technology transfer mechanism (Antonov, Hristozov, 2017a).

\section{THE TERM “SCIENTIFIC AND TECHNOLOGICAL RESERVE” (RESEARCH AND TECHNOLOGY): EU'S EXPERIENCE.}

The formations of a technological broker in the defense sector on EU level happened relatively soon. In European papers this phenomenon is commonly associated with the term "Research \& Technology" (R\&T). For its part the term R\&T is related to the concept of Research \& Development (R\&D). „Research and Development" is the term closer to "scientific-research and experimental development" and very often is used in in various fields since the beginning of the 20th century.

The main idea is to collect data with which to build knowledge that is then used in different products and processes. The process of scientific research is usually structured in accordance with the "technology readiness levels/TRL" method. Technology readiness levels were first developed in NASA during the 80's and are designed to evaluate the maturity of emerging technologies (tools, materials, components, software, workflows, etc.) during the development process and sometimes in the early stages of operation.

Technology readiness levels are determined when assessing technological readiness the purpose of which is to study the program concept, technological requirements and demonstration capabilities.Different industries and countries point out different levels according to their characteristics but the general idea is well illustrated by Figure1. 


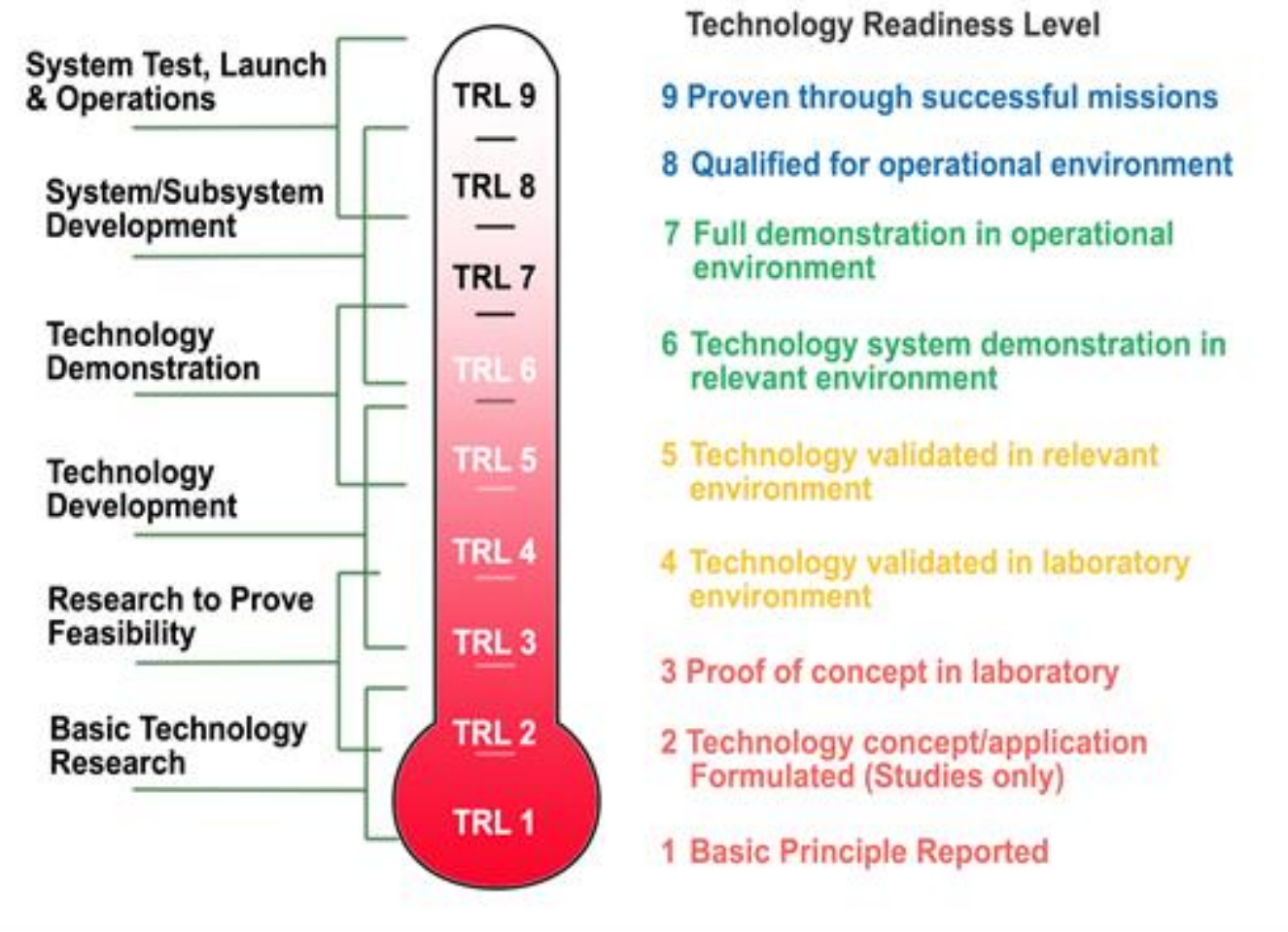

Figure 1. Reference: Data from the official site of the European defense agency: https://www.eda.europa.eu (accessed on November $7^{\text {th }}$ 2016.)

The method "technology reediness level" is based on a scale from 1 to 9 , where 9 is the most complete technology:

1. Basic principles observed and reported - the lowest level of technological readiness. Research conducted with an aim in applied research and developments the phase of scientific articles that discuss the main features of the technology;

2. Technology concept and/or application formulated -phase of inventions, scientific observation of physical phenomena, study of the theoretical applications of the technology;

3. Analytical and experimental critical function and/or characteristic proof of concept - start of the active phase of R\&T - analytical and laboratory studies, experimental verification of analytical forecasts;

4. Component and/or breadboard validation in laboratory environment - the main components of the technology are integrated and their performance is evaluated a separate node on the platform;

5. Component and/or breadboard validation in relevant environment - the technology is integrated with other carrier elements and is tested in a simulated environment;

6. System/subsystem model or prototype demonstration in a relevant environment - a representative model or prototype of the technology is tested in laboratory conditions or in a simulation platform;

7. System prototype demonstration in an operational environment - the prototype is tested in a system or platform;

8. Actual system completed and qualified through test and demonstration - the technology has proven its effectiveness in its final form and has met the expected requirements, test and performance evaluations are conducted on the intended system or platform;

9. Actual system proven through successful mission operations - field testing of the whole system or platform.

The use of such a tool provides a consistent and uniform discussion for technical readiness between different types of technology. The definition of the term in different organizations, institutions and departments in different countries and at different times changes periodically. 


\section{Term "Research and Technology (R\&T)"}

\section{Technological broker}

The term was first described in the late 1980s by Professor Andrew Hargadon from the California university. He proposes the following: "A technology broker aims to cover on the one hand a system of complex structures and on the other different industries in order to understand how existing technologies can be used to create breakthrough innovations in other market niches". Or "Technology mediation can teach businesses to effectively shift the focus of traditional R\&D teams that create brand new products to combine with previous innovations". For this purpose the formation of the following tasks is suggested:

- Collection of good ideas;

- Support of good ideas (knowledge management system);

- Generating new applications for old ideas;

- Verification of respective concepts.

Andrew Hargadon primarily links this process with technology gathering as an information base for recombining existing technologies with a view to further commercialize them.

Apparently the emergence of technological mediation is the result from a set of factors that are developing in parallel. The first attempts to use technological mediation were made in the US in the civilian sector. Its main task are to collect technological data from completely different fields. Subsequently, the technology broker begins to pursue broader tasks. Andrew Hargadon describes the term for commercial use in the US civilian open market. But the author is more interested in the term's defense application. it would be interesting to look at the definition of the term given by the European Space Agency. According to their definition the task of the technology broker is to assess the needs of the market in those areas where there is a potential application of the technologies. The broker also maintains a database of all technologies available on the market and compares them with the technologies required by the market. In addition, brokers support the technology transfer process between all market participants. The European Space Agency gives a very precise definition of the term technology broker in accordance with defense.

A technological broker in the defense sector is a mediator between the state the industry and the science. This mediator possesses information and maintains a database about all technologies, know-how, scientific research, results of intellectual work, organizational and management methods and production experience. $\mathrm{He}$ then compares them with technologies which are required both by the state in the face of various agencies and by the industry. Accordingly he can then assess the potential of the technology's application in relevant areas (the so-called "technology audit"). The role of industry however can be fulfilled not only by the military-industrial enterprises-giants but also from the business environment in general the small and medium enterprises (both in the civilian and military segments) venture capital. In the modern world the vast amount of accumulated knowledge requires to be studied and developed furthermore the emergence of new disciplines that research the use of existing technologies. The technology broker along with the legal rules is not only an important technology transfer mechanism and information storage system, but also performs:

- Audit of available technologies in the country and the world;

- Adaptation (assessment, classification, standardization, additional R\&D, research of technology combination, know-how, research of technology applications and, etc.);

\section{- Are committed to their distribution and commercialization.}

If the technology broker in the defense sector is unified and state-owned a natural step would be to give this system-mediator the power to transfer technology from the military to the civilian sector and vice versa. This can only be achieved with an appropriate regulatory framework that would facilitate transfer. One such example is the grant of a patent to an inventor or a team of inventors and the organization (within which the invention was created) on the basis of which the inventor, team, and organization will receive rewards from the further commercialization of technology from a technology broker in the form of transfer of an appropriate license to an enterprise. For the right to use this invention in its products or in the provision of services. Accordingly an administrative mechanism regarding technological transfer should be developed. The task of a state technology broker may also involve the collection and exchange of data between other private, corporate and industrial technology brokers or a national and / or international network of technology brokers (Angelov, 2015; Angelov, 2016-a). 


\section{TECHNOLOGY BROKER IN THE EUROPEAN UNION}

The creation of a technology broker in the defense sector within the European Union is relatively recent. The process proceeds gradually following its logic. The EU-wide strategy for the development of defense research is reflected in all EU strategic documents and is the basis for the development of cooperation measures. One of the first steps towards developing a cooperative mechanism for participating countries is seen in a better understanding of the territorial distribution of European research laboratories. These laboratories are also aimed in the creation of a reliable source for the collection and storage of information on defense research competencies. In April 2008, with the support of Germany and France an attempt was made to set up European Defense Research Centers (Tsanov, 2002; Tsanov, 2015; Tsanov, 2010).

On the basis of common interests EU Member States support the project that reflects the overall picture of the availability of various know-hows in the field of defense technology and decides to develop this database. The implementation of this initiative has been entrusted to the European Defense Agency's scientific department. In April 2009 the Internet portal was launched and in September 2009 all participating countries were invited to fulfill their relevant databases. The database of the European Defense Technology Center is considered as a simple tool for gathering information on the availability of certain knowledge and skills in the field of defense research and as a result an attempt to organize cooperation first between defense scientific organizations and then other scientific and research institutions.

This European Center is also a useful mechanism for the European Defense Agency in cases where research expertise is needed. Initially the center's main objective was to list all defense research institutions in its database. Later the possibility of including research teams working in small and medium-sized enterprises was also considered in the database.

Other sections of the European Defense Agency together with some participating countries propose to add to the database information about test centers and training sites. In 2010 Poland conducted an analysis on the shortcomings of the website which resulted in a number of changes. And in 2011 the European portal officially began its work. The European center for scientific research in the field of defense is in fact an attempt for the creation of a single supranational technology broker of the European Union's defense sector. The tasks of the European Technology Broker can be summarized as follows (Terziev, 2019-h; Terziev, 2018n-q).

- Provides a geographical representation of the available institutes for defense research and identifies their area of interest and technology ownership. The data in these institutes is classified according to two programs: "Systematic technologies of the European Defense Agency" and "Development of modern defense technologies";

- Facilitates the identification of experts and databases in different fields where collaboration is possible and innovations are expected;

- Functions as a reliable search engine for the organization of internal and external partnerships and/or acts as an expert for EU Member States and the European Defense Agency as a whole. Such an informational web portal also enables the formulation of business offers and their public insertion through different technologies. In summary it can be said that the database of the European Defense Research Center is intended to ensure synergies and co-operation in the field of technology transfer between governments of the EU Member States, industry, research institutions and the European Defense Agency (Terziev, Bankov, Georgiev, 2018b-c).

\section{CONCLUSION}

Update on question about the integration of the defense industry in the contest of more clear specialization in the weapons and weaponry supply chain is inevitable. Currently European countries prefer to cooperate with each other as well as with the United States. Taking into account the agenda of "strategic autonomy" the EU will move towards inner European internationalization and integration of the defense-industrial complex. The intra-European integration of the defense-industrial complex will be particularly intense in areas where the EU lacks technology especially compared to the US. These areas and technologies are mentioned in EU doctrinal documents where their development has been declared as the main focus of co-financing, development and manufacturing efforts. Such technologies include transport and unmanned aerial vehicles, spacecraft and electronic reconnaissance, target recognition and targeting systems, electronic warfare, guided weapons, anti-aircraft and missile defenses. Taking into account the policy on "strategic autonomy" in the field of defense and security the European Union will have to fill its technological gaps. In this sense the potential for a mutually beneficial cooperation between the EU and other countries excluding the US can be increased (Terziev, Petkov, Krastev, 2018d-m). 


\section{REFERENCE LIST}

Antonov S.I, Hristozov I.S (2018). Information systems for armament and equipment exploitation control, Sbornik dokladi ot Mezhdunarodna nauchna konferentsiya na Voenna akademiya "Georgi Stoykov Rakovski” - „105 godini znanie v interes na sigurnostta i otbranata“ 6 - 7 april 2017 g., Sofiya, 2018, str. 268-374, ISBN 978-619-7478-00-6 (Antonov S.I, Hristozov I.S, Information systems for armament and equipment exploitation control, Сборник доклади от Международна научна конференция на Военна академия „Георги Стойков Раковски” - „105 години знание в интерес на сигурността и отбраната“" 6 - 7 април 2017 г., София, 2018, стр. 268-374, ISBN 978-619-7478-00-6).

Antonov S.I. (2017). Comparative analysis of the armament and equipment support modules in the field of command and control information systems of NATO armies, International Scientific Journal "SECURITY \& FUTURE", Year I, Issue 4, 2017, pp. 163-167, WEB ISSN 2535-082X; PRINT ISSN 2535-0668.

Antonov S.I, Hristozov I.S. (2017a). Otsenka na vazmozhnostite na polevite sistemi za komandvane i upravlenie za poddarzhane na eksploatatsiyata na vaorazhenieto i tehnikata, Sbornik dokladi ot godishnata nauchna konferentsiya na fakultet "Natsionalna sigurnost i otbrana" - "Savremenni predizvikatelstva pred sigurnostta i otbranata", 18 - 19 may 2017 g., Parva chast, Voenna akademiya "Georgi Stoykov Rakovski“, Sofiya, 2017, str. 99-104, ISBN 978-954-9348-92-7 (Антонов С.И, Христозов И.С, Оценка на възможностите на полевите системи за командване и управление за поддържане на експлоатацията на въоръжението и техниката, Сборник доклади от годишната научна конференция на фракултет „Национална сигурност и отбрана“ - "Съвременни предизвикателства пред сигурността и отбраната", 18 - 19 май 2017 г., Първа част, Военна академия „Георги Стойков Раковски“, София, 2017, стр. 99-104, ISBN 978-954-9348-92-7).

Angelov, Ivaylo. (2015). Aviatsionnoto obrazovanie v usloviyata na globalizatsiya. // Sbornik dokladi ot Godishnata universitetska nauchna konferentsiya na NVU „Vasil Levski” 2015, tom 10, s. 99-108, Izdatelski kompleks na NVU „Vasil Levski”, Veliko Tarnovo, 2015, ISSN 1314-1937 (Ангелов, Ивайло. Авиационното образование в условията на глобализация. // Сборник доклади от Годишната университетска научна конфреренция на НВУ „Васил Левски” 2015, том 10, с. 99-108, Издателски комплекс на НВУ „Васил Левски”, Велико Търново, 2015, ISSN 1314-1937).

Angelov, Ivaylo. (2016). Politika na evropeyskiya sayuz za razvitieto na aviatsiyata i aviatsionnoto obrazovanie. // Yubileyna nauchna konferentsiya 14 - 15 april 2016 g., Fakultet “Aviatsionen” NVU „V. Levski"- Dolna Mitropoliya, s.301-311, 2016, ISBN 978-954-713-109-5 (Ангелов, Ивайло. Политика на европейския съюз за развитието на авиацията и авиационното образование. // Юбилейна научна конференция 14 - 15 април 2016 г., Факултет “Авиационен” НВУ „В. Левски”- Долна Митрополия, с.301-311, 2016, ISBN 978-954-713-109-5).

Angelov, Ivaylo. (2016a). Vissheto aviatsionno obrazovanie v drugi evropeyski darzhavi. // Sbornik ot dokladi na Yubileyna nauchna konferentsiya 14 - 15 april 2016 g., Fakultet” Aviatsionen” NVU „V. Levski”Dolna Mitropoliya, s.292-300, Elektronno izdanie, 2016, ISBN 978-954-713-109-5 (Ангелов, Ивайло. Висшето авиационно образование в други европейски държави. // Сборник от доклади на Юбилейна научна конфреренция 14 - 15 април 2016 г., Факултет” Авиационен” НВУ „В. Левски”Долна Митрополия, с.292-300, Електронно издание, 2016, ISBN 978-954-713-109-5).

Tsanov, Emil. (2002), Sovremennaye podhoday upravleniya korporativnoy informatsiey (savremenni podhodi za upravlenie na korporativnata informatsiya), Visnik donetsykogo universitetu, 5, br. 1, s. 139-145, 2002, ISSN 1817-2261 (Цанов, Емил. Современные подходы управления корпоративной информацией (съвременни подходи за управление на корпоративната информация), Вісник донецького університету, 5, бр. 1, с. 139-145, 2002, ISSN 1817-2261).

Tsanov, Emil. (2015). Kontseptsiya za sotsialno-orientirano upravlenie na biznes informatsiyata, Evropeyski praktiki i natsionalni refleksii $v$ planiraneto, Mezhdunarodna yubileyna nauchno-prakticheska konferentsiya: sbornik dokladi - Svishtov, 24-25 april 2015 g., s. 369-375, 2015, ISBN 978-954-231075-4 (Цанов, Емил, Концепция за социално-ориентирано управление на бизнес информацията, Европейски практики и национални рефрлексии в планирането, Международна юбилейна научно-практическа конференция: сборник доклади - Свищов, 24-25 април 2015 г., с. 369-375, 2015, ISBN 978-954-23-1075-4).

Tsanov, Emil (2010). Biznes inteligentnite tehnologii - kritichno vazhni za napredaka na sredniya biznes v Balgariya, Sistemi za upravlenie na biznesa v malki i sredni predpriyatiya: mezhdunarodna nauchna konferentsiya - Svishtov, 23-24 april 2010 g., s. 223-229, 2010, ISBN 978-954-23-0455-5 (Цанов, 
Емил, Бизнес интелигентните технологии - критично важни за напредъка на средния бизнес в България, Системи за управление на бизнеса в малки и средни предприятия: международна научна конференция - Свищов, 23-24 април 2010 г., с. 223-229, 2010, ISBN 978-954-23-0455-5).

Terziev, V., Bankov, S., Georgiev, M. (2018b).The Change in the approach of the court of justice of the European Union in the context of market freedoms and internal situations. // Journal of Innovations and Sustainability, Plovdiv, Bulgaria, 4, 2018, 3, pp. 85-112, ISSN 2367-8127 (CD-ROM), ISSN $2367-$ 8151 (on-line).

Terziev, V., Bankov, S., Georgiev, M. (2018c). The Stability and growth pact: pursuing sound public finances and coordinating fiscal policies in the EU member states. // Journal of Innovations and Sustainability, Plovdiv, Bulgaria, 4, 2018, 3, pp. 53-68, ISSN 2367-8127 (CD-ROM), ISSN 2367-8151 (on-line).

Terziev, V., Petkov, M., Krastev, D. (2018d). Operative mode for police cooperation between the member states of the European Union. // Proceedings of SOCIOINT 2018- 5th International Conference on Education, Social Sciences and Humanities, 2-4 July 2018- Dubai, U.A.E, International Organization Center of Academic Research, www.ocerints.org, 2018, pp.473-476, ISBN: 978-605-82433-3-0.

Terziev, V., Petkov, M., Krastev, D. (2018e). European arrest warrant: appearance and preferences for fulfillment. // Proceedings of SOCIOINT 2018- 5th International Conference on Education, Social Sciences and Humanities, 2-4 July 2018- Dubai, U.A.E, International Organization Center of Academic Research, www.ocerints.org, 2018, pp. 477-481, ISBN: 978-605-82433-3-0.

Terziev, V., Petkov, M., Krastev, D. (2018f). Eurojust casework on mafia-type criminal organisations. // Proceedings of SOCIOINT 2018- 5th International Conference on Education, Social Sciences and Humanities, 2-4 July 2018- Dubai, U.A.E, International Organization Center of Academic Research, www.ocerints.org, 2018, pp.487-491, ISBN: 978-605-82433-3-0.

Terziev, V., Petkov, M., Krastev, D. (2018g). Concept of joint investigation teams. // Proceedings of SOCIOINT 2018- 5th International Conference on Education, Social Sciences and Humanities, 2-4 July 2018- Dubai, U.A.E, International Organization Center of Academic Research, www.ocerints.org, 2018, pp.492-496, ISBN: 978-605-82433-3-0.

Terziev, V., Petkov, M., Krastev, D. (2018h). European arrest warrant and human rights of the accused. // Proceedings of SOCIOINT 2018- 5th International Conference on Education, Social Sciences and Humanities, 2-4 July 2018- Dubai, U.A.E, International Organization Center of Academic Research, www.ocerints.org, 2018. pp.501-504, ISBN: 978-605-82433-3-0.

Terziev, V., Petkov, M., Krastev, D. (2018i). Pumps for the action on the European Union in the scope of the European agenda on security. // Proceedings of SOCIOINT 2018- 5th International Conference on Education, Social Sciences and Humanities, 2-4 July 2018- Dubai, U.A.E, International Organization Center of Academic Research, www.ocerints.org, 2018, pp.497-500, ISBN: 978-605-82433-3-0.

Terziev, V., Petkov, M., Krastev, D. (2018j). The process of forming a criminal policy of the European Union. // Proceedings of SOCIOINT 2018-5th International Conference on Education, Social Sciences and Humanities, 2-4 July 2018- Dubai, U.A.E, International Organization Center of Academic Research, www.ocerints.org, 2018, pp.505-510, ISBN: 978-605-82433-3-0.

Terziev, V., Petkov, M., Krastev, D. (2018k). Organization on the European Union in the sphere of penal preparation. // Proceedings of SOCIOINT 2018- 5th International Conference on Education, Social Sciences and Humanities, 2-4 July 2018- Dubai, U.A.E, International Organization Center of Academic Research, www.ocerints.org, 2018, pp.482-486, ISBN: 978-605-82433-3-0.

Terziev, V., Petkov, M., Krastev, D. (2018I)Sources of European Union law. // Proceedings of SOCIOINT 2018- 5th International Conference on Education, Social Sciences and Humanities, 2-4 July 2018Dubai, U.A.E, International Organization Center of Academic Research, www.ocerints.org, 2018, pp.511-516, ISBN: 978-605-82433-3-0.

Terziev, V., Petkov, M., Krastev, D. (2018m).The „Source of law“ category. // Proceedings of SOCIOINT 2018- 5th International Conference on Education, Social Sciences and Humanities, 2-4 July 2018Dubai, U.A.E, International Organization Center of Academic Research, www.ocerints.org, 2018, pp.517-521, ISBN: 978-605-82433-3-0.

Terziev, Venelin. (2019). Retraining of the discharged and the ones leaving active military service as a tool for their social and professional mobility. // Proceedings of SOCIOINT 2019- 6th International Conference on Education, Social Sciences and Humanities 24-26 June 2019- Istanbul, Turkey, 
International Organization Center of Academic Research, Istanbul, Turkey, 2019, pp. 452-461, ISBN: 978-605-82433-6-1.

Terziev, Venelin. (2019a). The dependence social adaptation- socialization. // INTCESS 2019- 6th International Conference on Education and Social Sciences, 4-6 February, 2019, Dubai, International Organization Center of Academic Research, Istanbul, Turkey, pp. 478-485, ISBN: 978-605-82433-5-4.

Terziev, Venelin. (2019b). Social adaptation of military servicemen, discharged from military service, in dynamic social environment. // INTCESS 2019- 6th International Conference on Education and Social Sciences, 4-6 February, 2019, Dubai, International Organization Center of Academic Research, Istanbul, Turkey, pp. 486-493, ISBN: 978-605-82433-5-4.

Terziev, Venelin. (2019c). Conceptual framework of social adaptation. // INTCESS 2019- 6th International Conference on Education and Social Sciences, 4-6 February, 2019, Dubai, International Organization Center of Academic Research, Istanbul, Turkey, pp. 494-503, ISBN: 978-605-82433-5-4.

Terziev, Venelin. (2019d). Model for social-psychological assistance for servicemen, discharged from military service. // INTCESS 2019- 6th International Conference on Education and Social Sciences, 4-6 February, 2019, Dubai, International Organization Center of Academic Research, Istanbul, Turkey, pp. 504-513, ISBN: 978-605-82433-5-4.

Terziev, Venelin. (2019e). Social adaptation as an element of social policy. // INTCESS 2019- 6th International Conference on Education and Social Sciences, 4-6 February, 2019, Dubai, International Organization Center of Academic Research, Istanbul, Turkey, pp. 514-521, ISBN: 978-605-82433-5-4.

Terziev, Venelin. (2019f). Analysis of the Bulgarian experience in the development of the social adaptation of servicemen, discharged from military service. // INTCESS 2019- 6th International Conference on Education and Social Sciences, 4-6 February, 2019, Dubai, International Organization Center of Academic Research, Istanbul, Turkey, pp. 522-534, ISBN: 978-605-82433-5-4.

Terziev, Venelin. (2019g). Complex model of social adaptation of servicemen, discharged from military service. // INTCESS 2019- 6th International Conference on Education and Social Sciences, 4-6 February, 2019, Dubai, International Organization Center of Academic Research, Istanbul, Turkey, pp. 535-545, ISBN: 978-605-82433-5-4.

Terziev, Venelin. (2019h). Social activity and human resources as social development factors. // INTCESS 2019- 6th International Conference on Education and Social Sciences, 4-6 February, 2019, Dubai, International Organization Center of Academic Research, Istanbul, Turkey, pp. 546-553, ISBN: 978605-82433-5-4.

Terziev, Venelin. (2018n). Bulgarian experience in the development of social adaptation of military personnel, discharged from military service and their families. // ADVED 2018- 4th International Conference on Advances in Education and Social Sciences Abstracts \& Proceedings, 15-17 October 2018- Istanbul, Turkey, International Organization Center of Academic Research, www.ocerints.org, Istanbul, Turkey, 2018, pp. 213-227, ISBN: 978-605-82433-4-7.

Terziev, Venelin. (20180). Opportunities of aplication of a competence-based approach in social adaptation of militaries discharged of service. // ADVED 2018- 4th International Conference on Advances in Education and Social Sciences Abstracts \& Proceedings, 15-17 October 2018- Istanbul, Turkey, International Organization Center of Academic Research, www.ocerints.org, Istanbul, Turkey, 2018, pp. 237-247, ISBN: 978-605-82433-4-7.

Terziev, Venelin. (2018p). Possible aspects of occupational and psychological adaptation of the military, discharged from military service and their families to a new activity life cycle. // ADVED 2018- 4th International Conference on Advances in Education and Social Sciences Abstracts \& Proceedings, 1517 October 2018- Istanbul, Turkey, International Organization Center of Academic Research, www.ocerints.org, Istanbul, Turkey, 2018, pp. 256-265, ISBN: 978-605-82433-4-7.

Terziev, Venelin. (2018q). Realities of implementing the social adaptation process of military personnel, discharged form service in Bulgaria. // ADVED 2018- 4th International Conference on Advances in Education and Social Sciences Abstracts \& Proceedings, 15-17 October 2018- Istanbul, Turkey, International Organization Center of Academic Research, www.ocerints.org, Istanbul, Turkey, 2018, pp. 266-276, ISBN: 978-605-82433-4-7. 